\section{B A Institute of \\ YK Business Administration \\ 六下 \\ Karachi \\ Leadership and Ideas for Tomorrow}

Business Review

Volume 5 Issue 1 January-June 2010

$1-1-2010$

\title{
Chocolate brand familiarity and product-country evaluation among young consumersin Malaysia
}

\author{
Poh-Chuin Poh-Chuin \\ School of Management, Universiti Sains Malaysia, Malaysia \\ Osman Mohamad \\ Graduate School of Business, Universiti Sains Malaysia, Malaysia \\ Yudi Fernando \\ School of Management, Universiti Sains Malaysia, Malaysia
}

Follow this and additional works at: https://ir.iba.edu.pk/businessreview

Part of the Marketing Commons, and the Sales and Merchandising Commons

\section{cc) (7)}

This work is licensed under a Creative Commons Attribution 4.0 International License.

\section{Recommended Citation}

Poh-Chuin, P., Mohamad, O., \& Fernando, Y. (2010). Chocolate brand familiarity and product-country evaluation among young consumersin Malaysia. Business Review, 5(1), 117-130. Retrieved from https://doi.org/10.54784/1990-6587.1260 


\title{
ARTICLE
}

\section{Chocolate Brand Familiarity and Product-Country Evaluation Among Young Consumers In Malaysia}

\author{
Poh-Chuin Teo \\ School of Management \\ Universiti Sains Malaysia, Malaysia \\ Osman Mohamad \\ Graduate School of Business \\ Universiti Sains Malaysia, Malaysia \\ Yudi Fernando \\ School of Management \\ Universiti Sains Malaysia, Malaysia
}

\begin{abstract}
Consumers' product evaluation and brand familiarity are important in the marketing arena, considering the significant growth of the international trade and globalization. This study tries to identify young Malaysian's chocolate brand familiarity and product-country evaluation. The results found that stereotyping and halo effects do influence young Malaysian chocolate evaluation. The discussion of this study also includes recommendation to marketing managers and research limitations.
\end{abstract}

Keywords : Country-of-origin, Stereotyping, Young Consumer; Malaysia

\section{Introduction}

Brand image research has long been recognized as one of the central areas of the marketing research field (Keller, 1993). A good brand image can act as a facilitator that provides added value to the customer by giving supplementary information and meaning. Brand names are gaining importance as a valuable asset for many companies in international marketing. The country origin of brand also has become much more important from time to time. Country-of-origin (hereinafter called as $\mathrm{COO}$ ) has become one of the most widely researched areas in international marketing discipline (Papadopoulos \& Heslop, 2002), as the growth volume and diversity of international trade has led to an increasing number of consumer decisions which involve product COO (Nayir \& Durmusoglu, 2008). 
Most of the COO researches have been conducted in Western and developed countries. The meta-analysis of Usunier (2006) showed that most of the COO surveys were administered in USA, followed by France, UK, Canada, Japan and Germany. Hence, it has become important to conduct the research in the Southeast-Asian countries, because Southeast-Asian economies have seen strong growth in terms of the capacity of both consumption and production (O'Cass and Lim, 2002). In addition, future researchers are encouraged to examine the effects of COO based on segmentation (Kwok, Uncles \& Huang, 2006), as different customer segments in different countries respond differently and the effects of COO cannot be fully understood without considering them (Bhaskaran \& Sukumaran, 2007). O'Cass and Lim (2002) pointed out the importance of conducting with $\mathrm{COO}$ research on young consumers, as they are the prime target of most of the commercial marketing activity.

Furthermore, Ahmed, Johnson, Xia, Chen, Han and Lim. (2004) claimed that it is not clear what role COO plays in shaping consumers' buying behavior to such goods or whether the effect of $\mathrm{COO}$ is the same for low-involvement products as for highinvolvement products since there have been few studies on the impact of consumers' COO perceptions of low-involvement products. Moreover, world chocolate confectionery grew by $4 \%$ in current value terms to reach RM361 million in 2008 (Euromonitor International, 2008). But, multinationals continued to dominate chocolate confectionery in Malaysia (Euromonitor International, 2008). This emphasizes that chocolate confectionery is an important product to be investigated in Malaysia. The present empirical study is designed to examine the brand familiarity and product-country evaluation of the young consumers in Malaysia.

\section{Literature review}

Country-of-origin

$\mathrm{COO}$ is mainstream research in the field of marketing and consumer behavior (Usunier, 2006). It has been generally acknowledged that country of origin does influence consumers' product evaluations and purchase decisions (O'Cass \& Lim, 2002; Sohail, 2005; Chryssochoidis, Krystallis \& Perreas, 2007; Karunaratna \& Quester, 2007; Ahmed \& d'Atous, 2008). COO is defined as "the overall perception consumers form of products from a particular country, based on their prior perceptions of the country's production and marketing strengths and weaknesses" (Roth \& Romeo, 1992). Country-of-origin is regarded as an extrinsic cue, cognitively (Velegh \& Steenkamp, 1999), where the effect of $\mathrm{COO}$ is stronger when consumers are not familiar with the product category (Usunier, 2006). This is because, in the absence of information about tangible traits of products, consumers tend to rely on extrinsic cues as indirect indicators of quality and risk (Han, 1988; Papadopoulos \& Heslop, 1993).

Consumer familiarity towards brand and product influence the effects of COO. Some researchers argue that consumer knowledge of a brand's country is crucial for the 
transfer of the COO image to the brand image; however, they are hardly likely to be able to transfer any perceived COO image to the brand when they do not know about a brand's COO (Paswan \& Sharma, 2004). It is believed that consumer knowledge and expertise play a central role as to which type of generalization may be formed on the basis of this information. Less knowledgeable consumers are considered to use brand name and $\mathrm{COO}$ in a more general manner while more knowledgeable or expert consumers may use this information in a conditional fashion (Han, 1989; Hong, Pecotich \& Schultz, 2002). As consumers become more familiar with the product, their ability to assess product quality based on their knowledge of intrinsic attributes, that are informative about quality, improves.

Moreover, empirical evidence has shown that there is a positive relationship between product evaluations and degree of economic development, with products made in less-developed countries usually rated by consumers as inferior to those manufactured in more-developed countries (Schooler, 1971; Wang \& Lamb, 1983). The higher the level of industrialization of a country, the more favorable is the perception of the quality of its workers which in turn is reflected in the perceived quality of its products (Ahmed $\&$ d'Atous, 2008). Furthermore, there are indications that products made in moredeveloped countries are considered more favorable, compared to their counterparts manufactured in less-developed countries (Ahmed \& d'Atous, 2008). Products made in countries, developing and less developed, characterized by high-risk cause consumers to spend more time and effort in evaluating its attributes and performance before taking a final decision (Alden, 1993). Consumes tend to hold this stereotypic evaluation when they have a lower level of product familiarity. However, this stereotyping a lower decreases with the increase in consumer's level of involvement in the purchase decision. For instance, high-involved consumers in the purchase of a complex product are more informed about the technologically advanced manufacturing capacity of some Latin American countries and East Asian countries (Ahmed \& d'Atous, 2008). Thus they can appreciate the favorable price-quality relationship provided by the product from these countries.

\section{Stereotyping}

Model of Tricomponent Attitude reveals that attitudes consist of three major components, which are cognitive, affective and conative (Schiffman \& Kanuk, 2007). Country-of-origin has normative connotations, in the sense that the consumer's decision to purchase or avoid buying a country's products can be regarded as a vote in favor or against the policies, practices, or actions of a country (Verlegh \& Steenkamp, 1999). Furthermore, Erikson, Johansson and Chao (1984) based their observations of the formulation of stereotypical images on the "belief-attitude relationship", and suggested that there are three types of beliefs: informational, descriptive and inferential. These beliefs, it was supposed, are formed in different ways but all potentially contribute towards what a consumer believes about a product, i.e. there is a link between physical 
characteristics and product perceptions. They attribute the third (inferential) belief as contributing significantly to the formation of stereotypes.

Stereotyping is one psychological process that is commonly used to explain how consumers react to COO information (Maheswaran, 1994) and are used as standards to evaluate products from foreign countries affecting the cognitive processing of other product-related cues (Ahmed and d'Astous, 1996). Consumers tend to form their own evaluation of a product category based on their perception of the COO. For example, Malaysian consumers prefer products from a developed country, Japan, rather than a domestic brand (Yeong et al., 2007). In addition, consumers can reward "sympathetic" countries by purchasing their products (buycott), but punish "antipathetic" countries by refraining from buying their goods (boycott) (Smith, 1993). Since, country stereotypes may be negative or positive; the management of a product's national image is therefore an important element in the strategic marketing decision-making process of international firms (Al-Sulaiti \& Baker, 1998). Furthermore, the effects of country-of-origin on consumer behavior tend to vary from country to country, due to differences in economic, socio-cultural, political-legal, historical events, industrialization, degree of technological advancement and geographical closeness (Ahmd \& d'Atous, 2008; Nayir \& Durmusuglo, 2008). Within a specific country, they also tend to vary by time, because of changes in marketing sophistication, degree of industrialization, and lifestyle patterns (Papadopoulos \& Heslop, 1993). This has been proved by Nagashima who , in 1970 found that the US respondents perceived the Japanese products as cheap imitations of major US and Western Europe brands at 1970. However, latter research conducted in 1970 evaluation towards Japanese products has changed and improved.

Also, Erikson et al. (1984) found that COO influences belief formation rather than attitude in some studies although the effects of COO are not identical across all product attributes, and Johansson, Douglas and Nonaka. (1985) noted the existence of a persistent "halo" effect in ratings of specific product attributes. The information of origin plays a crucial role on consumer perception of brand by telling them the quality and value of a product. COO may influence consumers' attention and evaluation of other product dimensions, which may create a 'halo effect' (Erickson et al., 1984; Han, 1989). COO effects on product evaluations can occur in two different ways: "halo" and "summary" (Han, 1989).

COO plays as a role of "halo", when consumers are not familiar with the products of a country, that consumer used to infer beliefs about attributes that make up the attitudes towards a product or services (Han, 1989). On the other hand, a summary construct model served, when consumers are familiar with a country's products, in which consumers infer a country's image from its product information, which then indirectly influences brand attitudes (Han, 1989). In situations where consumers gain confidence in a country's products, it is possible that they may be predisposed to rely on $\mathrm{COO}$ as a halo construct to infer information about individual product attributes, 
thereby reducing the need for them to search for information relating to specific attributes of the product (Han, 1989).

This study tries to examine the brand familiarity and product-country evaluation of the young consumers in Malaysia. Foreign countries covered in this study are developed countries in order to examine the differences of the young consumers evaluation of various developed countries. Besides, this research also seeks to understand the influences of stereotypes and halo effects on brand familiarity and product-country evaluation, since brand name can function as a summary cue into which consumers consolidate past acquired information.

\section{Hypothesis Development}

This study is focused on young consumers in Malaysia, as Kwok et al (2006) has suggested that the future research could examine the impact of COO across different segments of consumers. The scholars argue that the different customer segments in different countries respond differently to such influences and $\mathrm{COO}$ effects cannot be fully understood without considering customer segments (Bhaskaran \& Sukumaran, 2007). Country-of-origin evaluations seem to be affected by the similarity perceived by consumers with their home countries in terms of economic, socio-cultural, politicallegal, and other environmental aspects (Papadopoulos, Heslop \& Beracs, 1990).

Moreover, empirical evidence has shown that there is a positive relationship between product evaluations and degree of economic development, with products made in less-developed countries usually rated by consumers as inferior to those manufactured in more-developed countries (Schooler, 1971; Wang \& Lamb, 1983). The higher the level of industrialization of a country, the more favorable is the perception of the quality of its workers (Li \& Monroe, 1992), which in turn is reflected in the perceived quality of its products (Iyer \& Kalita, 1997). Furthermore, there are indications that products made in more-developed countries are considered less risky, compared to their counterparts manufactured in less-developed countries (Hampton, 1977). Products made in countries characterized by high-risk cause consumers to spend more time and effort in evaluating its attributes and performance before taking a final decision (Alden et al., 1993). Moreover, in high-risk countries, it is more likely for the consumers to form a negative attitude about the product, which will subsequently reduce their willingness to buy it (Thorelli et al., 1989). This study tries to examine the differences of the young consumers' evaluation towards chocolate product from Malaysia and eight selected developed countries.

The consumer demographic characteristics such as gender (Johansson et al., 1985), age, and occupational groups (Shimp \& Sharma, 1987) were differently receptive to foreign products (Zhang, 1997). In addition, according to Han (1990), the halo hypothesis suggested that consumers may consider not buying an unfamiliar foreign 
brand simply because they may make unfavorable inferences about the quality of the brand from their lack of familiarity with products from the country. The findings of his study proved that the image of COO was affected by the consumer's perception of similarity between his or her own country's and the origin country's political and cultural climate and beliefs systems. Reviewing the literature on previous research, the researchers propose the research hypotheses as follows.

H1: There is a significant difference in chocolate brand familiarity among young consumers in Malaysia

$\mathrm{H} 2$ : There is a significant difference in chocolate country evaluation of young consumers of different gender .

H3: There is a significant difference among the young Malaysian's evaluation of chocolate of well known chocolate product from developed countries and other country

\section{Methodology}

In the current literature of marketing, many different methods for the measurement of COO have been described (Han, 1990). This empirical research is designed to examine and understand the young consumers' product-country evaluation in Malaysia. A selfcompletion questionnaire was administered to the students aged 18 to 30 in University Sains Malaysia. Students are selected to be the sample in this study because Verlegh and Steenkamp (1999), in their meta-analysis of COO literature, identified that there were no statistically different effects between the studies using student samples as compared to those studies using consumer samples. Convenience sampling was applied as sampling method in this study. 100 questionnaires were distributed randomly to the student, and the response rate was $100 \%$ as the questionnaires was passed to the subject by the researcher and completed with the presence of the researcher. All of the questionnaires were usable as the presence of researcher provided prompt feedback to the subject and the questionnaires were screened before the survey was completed.

The questionnaire consists of three parts. First part of the questionnaire aimed to collect respondent's demographic data likes age, gender, marital status and occupation. The second part was designed to measure respondent's evaluation towards product from Malaysia and eight such selected developed countries as:

$\begin{array}{ll}? & \text { Japan, } \\ ? & \text { Germany, } \\ ? & \text { US, } \\ ? & \text { New Zealand, } \\ ? & \text { Switzerland, } \\ ? & \text { Belgium, } \\ ? & \text { Denmark, and } \\ ? & \text { Italy }\end{array}$


Five-point Likert scales were chosen as measurement scales to collect data in this part of the questionnaire. Previous studies have indicated that Likert-scales are more reliable and appropriate for studies of this nature (Kaynak, Kucukemiroglu \& Hyder., 2000). Numerical values were assigned from 1 (low quality) to 5 (high quality) to measure the quality evaluation of chocolate products from those selected developed countries and home country. Lastly, the third part was designed to measure respondent level of familiarity towards various chocolate brand names from different countries. 19 chocolate brands are covered in this study including, foreign and domestic brands like Meiji, Tango, Ferrero Rocher, Van Houtan, Beryl's, Extreme. The measurement of this part was adopted from Ahmed and d'Atous (2008), where the scales are ranged from 1 (not familiar at all) to 5 (very familiar).

\section{Results and Discussions}

100 respondents are included in his survey and all of them are single students from University Sains , Malaysia. Of these 100 respondents , 10 are aged 20 years and below $(10 \%)$, and 90 belong to the age range of 21 to 30 years $(90 \%)$. In addition, 37 out of 100 respondents are males $(37 \%)$ and the rest of the $(63 \%)$ are females $(63 \%)$.

In order to understand the significant difference among chocolate brands by brand familiarities among young consumers in the Malaysia, Friedman Test on k-related sample was done on all the chocolate brands in Malaysian market. Results are shown below in Table 1.

Table 1

Difference Chocolate brand Familiarity

\begin{tabular}{|l|c|c|c|c|c|c|c|}
\hline Chocolate Brand & Mean & Std. Deviation & Mean Rank & Chi-Square & df & Asymp. Sig. & Brand Familiarity \\
\hline Smarties & 3.93 & 1.191 & 13.10 & 784.326 & 18 & .000 & 5 \\
\hline Kit Kat & 4.53 & .810 & 15.30 & & & & 1 \\
\hline Dars & 2.10 & 1.219 & 6.74 & & & & 15 \\
\hline Toblerone & 3.16 & 1.542 & 10.42 & & & & 9 \\
\hline Stella & 2.06 & 1.108 & 6.52 & & & & 16 \\
\hline Bourbon & 1.91 & 1.111 & 6.06 & & & & 19 \\
\hline Cadbury & 4.08 & 1.300 & 13.72 & & & & 4 \\
\hline Lindt & 2.22 & 1.411 & 7.35 & & & & 13 \\
\hline Van Houton & 2.81 & 1.587 & 9.22 & & & & 10 \\
\hline Marxies & 1.93 & 1.217 & 6.24 & & & & 17 \\
\hline Tango & 2.88 & 1.451 & 9.21 & & & & 11 \\
\hline Kandos & 1.97 & 1.159 & 6.17 & & & & 18 \\
\hline Meiji & 2.51 & 1.480 & 8.40 & & & & 12 \\
\hline Chrispy & 3.79 & 1.358 & 12.78 & & & & 6 \\
\hline M \& M & 4.35 & .968 & 14.78 & & & & 3 \\
\hline Ferrero Rocher & 4.50 & .948 & 15.18 & & & & 2 \\
\hline Beryls & 3.33 & 1.531 & 11.20 & & & & 7 \\
\hline Hersheys & 3.16 & 1.594 & 10.64 & & & & 8 \\
\hline Extreme & 2.13 & 1.195 & 6.96 & & & & 14 \\
\hline
\end{tabular}

Note: $* \mathrm{p}=<0.05 ; * * \mathrm{p}=<0.01 ; * *{ }^{*}<0.001 ; \mathrm{n}=100$ 
The results in Table 1 shows a significant difference among chocolate brands the chi-square showed result of 94.717 ( $\mathrm{p}<0.001$ ). Table 1 shows that Kit Kat was ranked as the most familiar chocolate product among young consumers, while Bourbon was the least familiar brand. Therefore, Hypothesis 1 is accepted. Young consumers' evaluation of chocolates from foreign developed countries and home country is shown in Table 2. The findings are interesting as respondents of different gender showed significant difference in chocolate country evaluation based on COO.

Table 2

The different between genders on chocolate country evaluation

\begin{tabular}{|l|c|c|c|c|c|}
\hline Country of Origin (COO) & M & Mean & F & Mean Difference & F value \\
\hline USA & 3.49 & & 3.43 & .058 & $4.791^{*}$ \\
\hline Switzerland & 3.76 & & 3.84 & -.085 & $5.512^{*}$ \\
\hline Japan & 3.35 & & 3.35 & .002 & $8.427^{* *}$ \\
\hline Italy & 3.57 & & 3.63 & -.067 & $8.688^{* *}$ \\
\hline Germany & 3.43 & & 3.41 & .020 & 3.098 \\
\hline UK & 3.89 & & 3.29 & .606 & .011 \\
\hline Malaysia & 2.76 & & 2.89 & -.132 & 3.158 \\
\hline New Zealand & 3.46 & & 3.78 & -.318 & $.018^{*}$ \\
\hline Denmark & 3.27 & & 3.30 & -.031 & 2.618 \\
\hline
\end{tabular}

Note: $* \mathrm{p}=<0.05 ; * * \mathrm{p}=<0.01 ; * * * \mathrm{p}<0.001 ; \mathrm{N}=$ Male $(37) \&$ Female $=(63)$

Table 2 shows significant difference in male and female respondents' chocolate country evaluation based on country of origin. The male respondents showed favorable evaluation on chocolate from England (Mean=3.89) and Switzerland (Mean=3.86). At the same time, female respondents that were evaluated with chocolate from Switzerland $(M e a n=3.84)$ and New Zealand (Mean=3.89) have higher quality. The chocolate from Switzerland was evaluated favorably to have high quality by male and female respondents. However, the chocolate from USA, Switzerland, Japan, Italy and New Zealand were statistically different with gender of respondents. But chocolate product from Germany, England, Malaysia and Denmark were found not significantly different with gender preference in consumer behavior. However, the $\mathrm{H} 2$ is accepted. Based on the results shown in Table 2, the respondents demonstrated favorable evaluation towards well known chocolate product from developed country compared to other countries. Regarding to the results in Table 2, the youth evaluate chocolate from Switzerland, New Zealand, USA and Italy were more favorably than chocolate from Malaysia. Hence, H3 is supported.

Stereotyping influenced the evaluation of the subjects of chocolates from different countries. The subjects evaluated the chocolate from developed countries better than chocolates from developing countries. For instance, based on the results from 
Table 2, both the male and female subjects evaluate chocolate from USA, Switzerland, Japan, Italy, Germany, UK, New Zealand, and Denmark to have higher quality than chocolate from Malaysia, which is home country. They have tendencies to evaluate chocolate product from home country as lower in quality. Those developed countries are economically more advanced than Malaysian, one of the developing countries in Southeast Asia. This preference is highly complex to be described as it involves a perceived disparity in the systems in terms of economics, cultural and political that are held by consumers in different markets (Wang \& Lamb, 1983; O'Cass \& Lim, 2002). In another setting, consumers from Sudan may evaluate product from Malaysia more favorable than consumers from the UK.

In addition, halo effects also play role in the subjects' brand and product $\mathrm{COO}$ evaluation. This study was set to seek out the effect of halo effect, by examining the respondents' evaluation of product $\mathrm{COO}$, and their brand familiarity without providing the $\mathrm{COO}$ of the brands. The findings have shown that halo effects exist in chocolate product among the young consumers in Malaysia. Overall, the respondents evaluate chocolate products from developed countries favorably. But based on Table 1, their familiarity towards chocolate brands from those countries showed mismatching results. For example, they evaluated brand Bourbon from Japan the least familiar, but evaluate chocolate from Japan have higher quality than chocolate from Malaysia and Denmark. Although they evaluated chocolate from Malaysia to have lowest quality compared to developed countries, but their familiarity towards chocolate brands from Malaysia is higher than chocolate brands from developed countries. The subjects' familiarity towards Malaysian chocolate brands such as Beryl's, Extreme and Crispy is higher than chocolate brands from developed countries such as Bourbon, Lindt, Marxies and others chocolate brands. The respondents have low familiarity to Marxies, chocolate brand ranked 17 from New Zealand, whereas female respondents chocolate from New Zealand as the second highest in terms of quality. Female evaluated chocolate from New Zealand highest in quality. This result can be described by the image of New Zealand where New Zealand is known as a 'clean green' source of food products (Gnoth, 2002).

\section{Conclusion and implications}

The results of this study demonstrated that the young consumers in Malaysia hold COO stereotyping on chocolate product. They evaluated chocolate product from developed countries more favorably than chocolate product from developing country, which is home country. Lumpkin and Crawford (1985) suggest that in the case of developing countries, national products tend to be evaluated less favorably than imported goods from developed countries. Marketers should consider this result when forming their marketing strategy and practices. Marketer should emphasize on the information of $\mathrm{COO}$ of chocolate from developed countries when designing communication message. Whereas marketer for chocolate from developing countries should focus on attribute rather than origin information. 
Interestingly, gender of the youth in Malaysia also play role in chocolate $\mathrm{COO}$ evaluation. Male and female respondents evaluate chocolate from various developed countries differently. Females evaluated chocolate from New Zealand the second highest in terms of quality, but the ranking is only fifth for males. This finding can be described by the country image and halo effects. New Zealand is known as a 'clean green' source of food products (Gnoth, 2002), and much effort has been made to promote this imagery, in the belief that the 'halo' associated with this image will enhance perceptions of New Zealand products (Knight, Holdsworth \& Mather, 2007). In addition, they also have different evaluation of chocolate from developed countries and developing country. These findings are crucial on market segmentation, targeting and positioning. Marketers are encouraged to use customized marketing strategy when they target different market segments in terms of the gender of young Malaysians.

\section{Limitations and recommendations}

In this research, the limitations exist in the design of questionnaire because the information of ethnicity could not be gained from this questionnaire. This limit to investigate the $\mathrm{COO}$ effect based on ethnicity, where ethnicity is crucial in Malaysian context as Malaysia consists of three major racial groups. Also, the results of this study may not be generalized as the questionnaire was distributed only in the campus of University Sains Malaysia. This is because the students of University Sains Malaysia cannot represent all Malaysians. But the level of this limitation is reduced because the samples are coming from different states in Malaysia, although they are only a small portion of all Malaysian. In addition, the findings of this study are restricted to chocolate product, so the results cannot be generalized to other product categories. The recommendations for future researchers are to increase the sample size, test another product category and try to collect data from different parts of Malaysia.

\section{References}

Ahmed, S.A. and d'Atous, A. (1996), "Country of origin and brand effects: a multi dimensional and multi-attributes study", Journal of International Consumer Marketing, Vol.9 No.2, pp.93-115

Ahmed, S.A. and d'Atous, A. (2008), “Antecedents, moderators and dimensions of country-of-origin evaluations", International Marketing Review, Vol.25 No.1, pp.75106

Ahmed, Z.U., Johnson, J.P., Xia, Y., Chen. K.F. Han. S.T. and Lim, C.B. (2004), "Does country of origin matter for low involvement products", International Marketing Review, Vol.21 No.1, pp.102-120

Alden, D.L., Hoyer, W.D. and Crowley, A.D. (1993), "Country of origin, perceived risk 
and evaluation strategy", Advances in Consumer Research, Vol.20 No.1, pp.678-683

Al-Sulaiti, K.I. and Baker, M.J. (1998), "Country of origin effects: a literature review”, Marketing Intelligence and Planning, Vol.16 No.3, pp.150-199

Banister, J.P. and Saunders, J.A. (1978), “UK consumers' attitudes towards imports: the measurement of national stereotype image", European Journal of Marketing, Vol.12 No.8, pp.562-570

Bhaskaran S. and Sukumaran N. (2007), "Contextual and methodological issues in COO studies", Marketing Intelligence \& Planning, Vol.25 No.1, pp.66-81

Cattin, P., Jolibert, A. and Lohnes, C. (1982), “A cross-cultural study of 'made-in' concepts", Journal of International Business Studies, Vol.13 No.3, pp.131-141

Chryssochoidis, G., Krystallis, A. and Perreas, P. (2007), "Ethnocentric beliefs and country-of-origin (COO) effect: impact of country, product and product attributes on Greek consumers' evaluation of food products", European Journal of Marketing, Vol.41 No.11/12, pp.1518-1544

Erickson, G.M., Johannson, J.K. and Chao, P. (1984), "Image variables in multiattribute product evaluations: country-of-origin effects", Journal of Consumer Research, Vol.11, pp.694-699

Euromonitor International (2008), "Chocolate confectionery - Malaysia", [Online]. [Accessed 21 th April 2009] Available from World Wide Web: http://www.portal.euromonitor.com/passport/Statistics.aspx

Euromonitor International (2009), "Market Sizes: Historic/Forecast", [Online]. [Accessed $22^{\text {nd }}$ April 2009] Available from World Wide Web:

http://www.portal.euromonitor.com/passport/Statistics.aspx

Gnoth, J. (2002), "Leveraging export brands through a tourism destination brand", Journal of Brand Management, Vol.9 No.4-5, pp.262-280

Hampton, G.M. (1977), "Perceived risk in buying products made abroad by American firms”, Buylor Business Studies, October pp.53-64

Han, C.M. (1988), "The role of consumer patriotism in the choice of domestic versus foreign products", Journal of Advertising Research, Vol.28 No.3, pp.25-32

Han, C.M. (1989), "Country image: halo or summary construct”, Journal of Marketing Research, Vol.26 May, pp.222-229

Han, C.M. and Terpstra, V. (1988), "Country-of-origin effects for uni-national and 
binational products", Journal of International Business Studies, pp.235-255

Han, S.M. (1990), "Testing the role of country image in consumer choice behavior", European Journal of Markerting, Vol.24 No.6, pp.24-40

Iyer, G.R.and Kalita, J.K. (1997), "The impact of country-of-origin cues on consumer perceptions of quality and value", Journal of Global Marketing, Vol.11 No.1, pp.7-28

Johansson, J.K., Douglas, S.P. and Nonaka, I. (1985), “Assessing the impact of country of origin on product evaluation: a new methodological perspective", Journal of Marketing Research, Vol.22, pp.388-396

Li, D. and Monroe, K.B. (1992), “The role of country of origin information on buyer's product evaluation: an in-depth interview approach", Enhancing Knowledge Development, Vol.3, Proceeding of the American Marketing Association Educator's Conference, pp. $274-280$

Lumpkin, J.R. and Crawford, J.C. (1985), "Consumer perceptions of developing countries", in Malhotra, N.K. (Ed.), Developments in Marketing Science, Vol. 8, Academy of Marketing Science, Coral Gables, FL, pp. 95-97

Karunaratna, A.R. and Quester, P.G. (2007), "Influence of cognition on product component country of origin evaluation", Asia Pacific Journal of Marketing and Logistics, Vol.19 No.4, pp.349-362

Kaynak, E., Kucukemiroglu, O. and Hyder, A.S. (2000), “Consumers' country-of-origin (COO) perceptions of imported products in a homogeneous less-developed country", European Journal of Marketing, Vol.34 No.9/10, pp.1221-1241

Keller, K.L. (1993), "Conceptualising, measuring, and managing customer based brand equity”, Journal of Marketing, Vol.57 January, pp.1-22

Knight, J.G., Holdsworth, D.K. and Mather, D.W. (2007), “Country-of-origin and choice of food imports: an in-depth study of European distribution channel gatekeepers", Journal of International Business Studies, Vol.38, pp.107-125

Kwok, S., Uncles, M. and Huang, Y. (2006), "Brand preferences and brand choices among urban Chinese consumers: an investigation of country-of-origin effects", Asia Pacific Journal of Marketing and Logistics, Vol.18 No.3, pp.163-172

Li, D. and Monroe, K.B. (1992), "The role of country of origin information on buyer's product evaluation: an in-depth interview approach", Enhancing Knowledge Development, Vol.3, Proceeding of the American Marketing Association Educator's Conference, pp. $274-280$ 
Maheswaran, D. (1994), "Country of origin as a stereotype: effects of consumer expertise and attitude strength on product evaluations", Journal of Consumer Research, Vol.21 No.2, pp.354-365

Nagashima, A. (1970), “A comparison of U.S. and Japanese attitudes towards foreign products”, Journal of Marketing, Vol.34, pp.68-74

Nagashima, A. (1977), “A comparative "made in" product image survey among Japanese businessmen", Journal of Marketing, Vol.41, pp.95-100

Nayir, D.Z. and Durmusoglu, S.S. (2008), "Country image in the context of European Union membership: the Turkish case", Journal of Management Development, Vol.27 No.7, pp.791-808

O'Cass, A. and Lim, K. (2002), “Understanding the younger Singaporean consumers' views of Western and Eastern brands", Asia Pacific Journal of Marketing and Logistics, Vol.14 No.4, pp.54-78

Paswan, A.K. and Sharma, D. (2004), "Brand-country of origin (COO) knowledge and COO image: investigation in an emerging franchise market", Journal of Product and Brand Management, Vol.13 No.3, pp.144-155

Papadopoulos, N. and Helop, L. (1993), Product-country image: impact and role in international marketing, International Business Press, New York, NY

Papadopoulos, N. and Heslop, L. (2002), "Country equity and country branding: problems and prospects", Journal of Product \& Brand Management, Vol. 9 No.4-5, pp.294-314

Papadopoulos, N., Heslop, L.A. and Beracs, J. (1990), "National stereotypes and product evaluations in a socialist country", International Marketing Review, Vol.7 No.1, pp.32-47

Roth, M.S. and Romeo, J.B.(1992), "Matching product category and country image perceptions: a framework for managing country-of-origin effects", Journal of International Business Studies, Vol.23 No.3, pp.477-497

Schiffman, L.G. and Kanuk, L.L. (2007) Consumer behaviour, $9^{\text {th }}$ ed., Pearson education: New Jersey

Schooler, R.D. (1971), "Bias phenomena attendant to the marketing of foreign goods in the US", Journal of International Business Studies, Vol.2, pp.71-81

Smith, W.R. (1993), "Country-of-origin bias: a regional labeling solution”, International Marketing Review, Vol.10 No.6, pp.4-12

Sohail, M.S. (2005), "Malaysian consumers' evaluation of products made in Germany: 
the country of origin effect", Asia Pacific Journal of Marketing and Logistics, Vol.17 No.1, pp.89-100

Thorelli, H.B., Lim, J. and Ye, J. (1989), "Relative importance of country of origin, warranty and retail store image on product evaluation", International Marketing Review, pp.35-46

Usunier, J. C. (2006), "Relevance in business research: the case of country-of-origin research in marketing", European Management Review, Vol.3, pp.60-73

Verlegh, P.W.J. and Steenkamp, J.E.M. (1999), “A review and meta-analysis of countryof-origin research", Journal of Economic Psychology", Vol.20, pp.521-546

Wang, C. and Lamb, C. (1983), "The impact of selected environmental forces upon consumers' willingness to buy foreign products", Journal of the Academy of marketing Science, Vol.11 No.2, pp.71-84

Yeong, N. C., Mohamad, O., Ramayah, R. and Omar, A. (2007), "Purchase [reference pf selected Malaysian motorcycle buyers: the discriminating role of perception of country of origin of brand and ethnocentrism”, Asian Academy of Management Journal, Vol.12 No.1, pp.1-22

Zhang, Y. (1997) "Country-of-origin effect: the moderating function of individual difference in information processing", International Marketing Review, Vol.14 No.4, pp.266-287.

Pleasure is a shadow, wealth is vanity, and power a pageant; but knowledge is ecstatic in enjoyment; perennial in fame, unlimited in space and infinite in duration. In the performance of its sacred offices, it fears no danger, spares no expense, looks in the volcano, dives into the ocean, perforates the earth, wings its flights into the skies, explores sea and land, contemplates the distant, examines the minute, comprehends the great, ascends to the sublime - no place too remote for its grasp, no height too exalted for its reach.

De Wilt Clinton 